\title{
CD43-Positive Neoplastic Cells Present
}

National Cancer Institute

\section{Source}

National Cancer Institute. CD43-Positive Neoplastic Cells Present. NCI Thesaurus. Code C72562.

An indication that expression of CD43 has been detected in a sample of neoplastic cells. 